\title{
The Performance Measurement Frameworks in Health Care: Appropriateness Criteria for Measuring and Evaluating the Quality-of-Care Performance through a Systematic Review
}

\begin{abstract}
Brahim Zaadoud $^{1 *}$, Youness Chbab ${ }^{2}$
${ }^{1}$ Clinical Neurosciences Laboratory, Faculty of Medicine and Pharmacy, University of Fez, Morocco

${ }^{2}$ The Institute of Specialized Health Professionals, University of My Slimane Bni Mellal, Morocco

Keywords:

Quality improvement, Health

care, Performance

measurement

\section{Received}

03 November 2021

Received in revised form

15 November 2021

Accepted

16 November 2021

*Correspondence:

Zaadoud@gmail.com

ABSTRACT

While quality management has become essential in the industrial field, it is still looking for a place in the social field. Experiences remain very divergent, and consensus on the appropriate method and effective tools is still far from being reached. This paper aims to review the literature in the field of performance measurement and management in health care. Studies concerning performance measurement and management in health in all settings were included. Studies before 2018 were identified from PubMed, Scopus, Web of Science, and Google Scholar. We conducted a thematic analysis of the international literature, identifying themes around the terms "performance assessment, performance evaluation, performance measurement, health indicators, conceptual framework, assessment framework, health system performance, and monitoring and evaluation. Thirty-seven articles were reviewed, and a set of conceptual frameworks were analyzed. Results were interpreted following the seven areas of the conceptual framework: Fundamental questions in performance evaluation, aims and objectives, role and goals, performance, conceptual frameworks, dysfunction of the health system, and performance assessment. All areas of care were involved, health promotion, preventive and curative care. For most organizations, performance measurement was in a relatively early stage of development or implementation. However, some dysfunctions were identified: a lack of systematic outcome assessment, a lack of documentation, a lack of resource evaluation related to quality for specific diseases, and persisting variations among providers in care for similar patients.
\end{abstract}


Quality management has been used in the industrial sector for more than 60 years and adapted to healthcare for almost 40 years. However, worldwide experiences are widely divergent for social systems, and there is no consensus on the appropriate manner and the effective and efficient tools. In addition, the field of health recognized by its complexity suffers from many problems, so the quality improvement of health care became an absolute priority and the main objective for any health system all over the world (Berwick, 2004 OCDE, 2011). The performance measurement of health care quality becomes essential to improve the quality, reduce the errors, and favor a bigger efficiency. The World Health Report identified three overall goals of a health care system: achieving good health for the population, ensuring that health services are responsive to the public, and ensuring fair payment systems (Veillard et al., 2005). According to Veillard et al. (2010), the health care system has three main objectives: 1) to give responsibilities to the persons receiving benefits of health, 2) to develop better-adapted politics, and 3) to allow the persons receiving benefits and the other stakeholders to exchange their knowledge. However, the quality of care is a concept difficult to seize because of the complexity of its evaluation (Piligrimienè \& Bučiūnienè, 2008). In addition, healthcare quality dresses multiple dimensions and can be understood according to various points of view (OCDE, 2011), such as the organization, configuration, and delivery of health care services, which affect the performance of the overall health system (Veillard et al., 2005). Despite the efforts supplied regarding research on the quality of care, considerable progress has been made in assessing the quality of care and implementing a wide range of quality improvement strategies (accreditation systems, certification, organizational quality management programs, clinical audit, patient safety systems, clinical practice guidelines, quality improvement collaborative, performance indicators and systems for getting patient views) (Groene et al., 2013).

The purpose of this review is to analyze the literature on performance assessment in health care to contribute to the selection of appropriate frameworks that can guide the measurement and evaluation of the quality of care.

\section{Methods}

\section{Research design}

A systematic review of the literature using a narrative synthesis approach (Snilstveit et al., 2012). We opted for a qualitative method based on the interpretive approach by analyzing the systems of measurement and management of performance in the field of health care through their components: the dimensions, the perspectives, and the different aspects of performance measurement in Primary Health Care Facilities "PHCE".

Criteria for considering studies in the review

peer-reviewed publication types, including literature reviews, quantitative studies, qualitative studies, mixed-methods studies, and discussion papers, were included and presented in Table 1.

Table 1

Summary of the Inclusion and Exclusion Criteria

\begin{tabular}{|l|l|}
\hline Inclusion criteria & Exclusion criteria \\
\hline Articles which described performance assessment in Health care. & non-peer reviewed literature \\
\hline Literature reviews, primary studies, and discussion papers & Commentaries, conference abstracts \\
\hline Articles written in English & \\
\hline Articles published between 2000-2020 & \\
\hline
\end{tabular}




\section{Search strategy}

We have considered in the review the publications focused on health performance assessment. The electronic databases were used to search for relevant articles: Medline, Cochrane. The following search terms were used: performance measurement, performance evaluation, performance assessment, and healthcare quality, shown in Table 2.

Table 2

The Search Strategy in the Databases

\begin{tabular}{|l|l|l|l|}
\hline Database & Search \# & Search term & Hits \\
\hline Medline, Cochrane & 1 & "Performance measurement".mp. & 962 \\
& 2 & "Performance measurement system".mp. & 2992 \\
& 3 & "Performance evaluation".mp. & 1387 \\
& 4 & "Performance assessment".mp. & 10214 \\
& 5 & OR/1-4 & 654805 \\
& 6 & "Quality of health care".mp. & 664947 \\
& 7 & 6 AND 5 & 1231 \\
& 8 & Minus duplicates & 628 \\
\hline
\end{tabular}

Limits were used to include only articles written in the English language and published between 2000-2020. The titles and abstracts of studies identified by the search strategy were independently assessed for eligibility by two reviewers (C.Y and E.S). The studies considered potentially relevant were examined in more detail.

\section{Quality assessment}

The study design of the included publications was determined using the hierarchy of evidence from the Medical Research Council guidelines (Craig et al., 2013). The study methodology was evaluated to examine evidence of performance assessment systems, tools, and barriers to performance assessment. However, the significant variability among the papers included in the study made it difficult to use a structured critical appraisal tool.

\section{Data extraction and analysis}

Content analysis was chosen because it can synthesize data from a wide range of literature (Pope et al., 2007) and is considered an appropriate method when the available data are descriptive (Snilstveit et al., 2012), which was the case in this systematic review. The content analysis approach for this review was inspired by the systematic review techniques reported by Evans and Fitzgerald (2002), which is a method that involves the development of categories and the coding of individual studies against these categories Mays et al., 2005). Several steps were used to analyze the evidence from individual studies. First, all included articles were read to develop an initial impression of the entire literature. Second, two reviewers worked collaboratively to identify recurring "key issues" from the individual studies, creating a list of initial categories. Each study provided data on a number of categories relevant to performance assessment. However, there is almost universal agreement that the criteria are not universal and that all three levels of performance (individual, organizational, and team) need to be considered, and that an organization must balance outcomes, processes, and resources to be successful.

\section{Results}

Literature base. The database search yielded 1231 articles and 14 articles identified through other sources, of which 623 were excluded due to duplicates and selection criteria. Six hundred 
twenty-two articles were screened by abstracts and titles. Thirty hundred twenty-four articles were deleted after reviewing the suitability of abstracts and titles. Two hundred ninety-eight articles underwent a complete review, of which two hundred twenty-two articles examined did not meet the inclusion criteria. Thus, the articles remaining for the study are seventy-six in number (see Appendix. A). The literature search chart is shown in Figure 1.

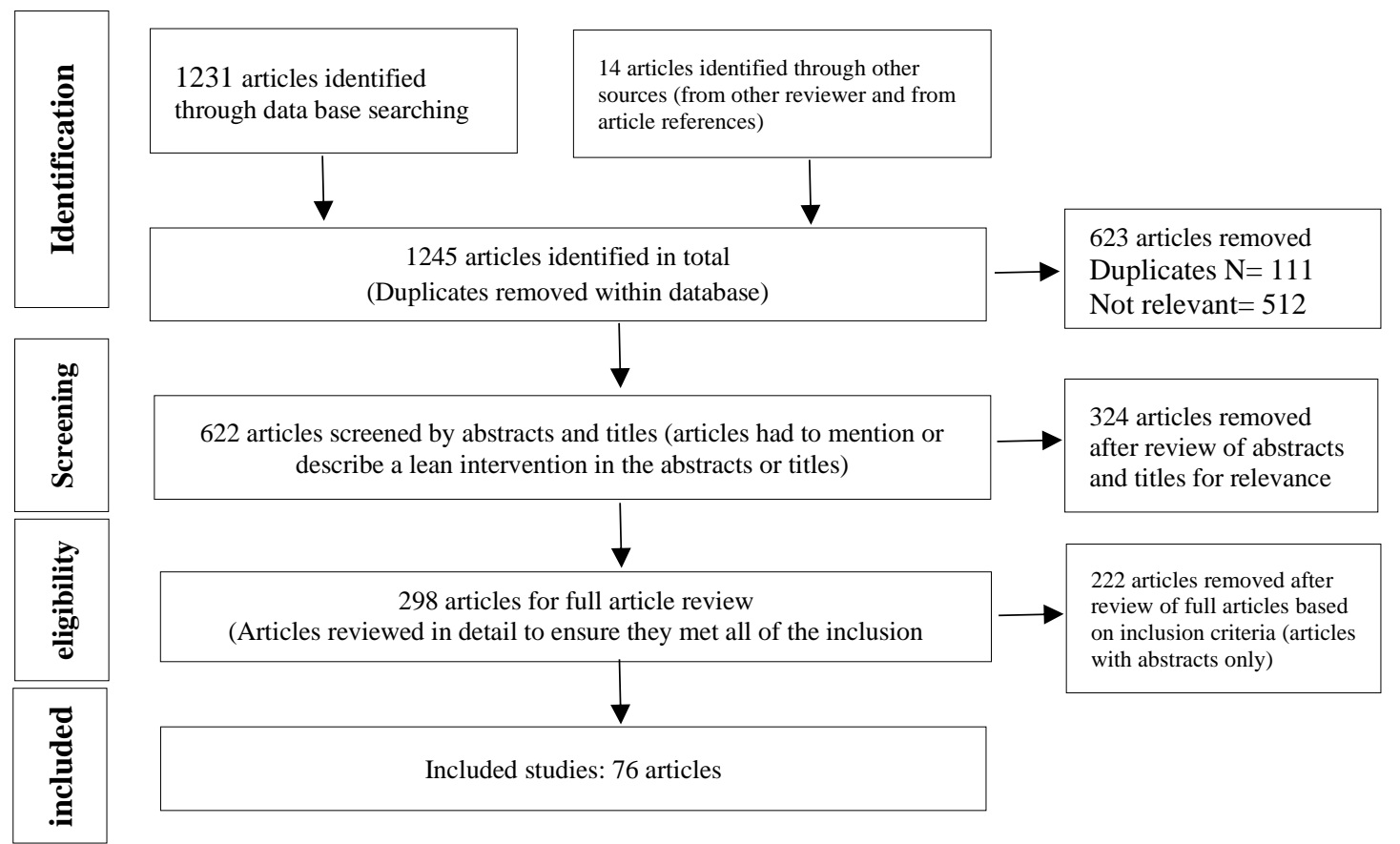

Figure 1. Systematic review process.

\section{Performance Evaluation System \\ Definition and domains of performance assessment}

There are numerous definitions of performance because of its complexity (Adair et al., 2003; Campbell et al., 2000), multidimensional (Sicotte et al., 1998), and paradoxical nature (Da Silva et al., 2011). Lizarondo et al. (2014) define performance evaluation as the process of collecting, computing, and presenting quantified constructs for the managerial purposes of following up monitoring and improving organizational performance (p. 5)'. Campbell 2000) has identified seven themes as the key domains for the development of performance indicators: the experience of the patient, the clinical activity, the development of the services and the innovation, the access, the promotion of the health, the efficiency of the costs, and the quality of the results of the life. The Institute Of Medicine (IOM) (as cited in Wolfe, 2001) and 'WHO' (2006) identified six domains of quality: 1) Effective, 2) efficient, 3) Accessible, 4) patient-centered, 5) Equity and 6) (WHO, 2006; Wolfe, 2001). Performance is often understood as a concept, which includes all the following notions: efficiency, effectiveness, yield, productivity, quality, access, and equity; it is based on organizational performance (Sicotte et al., 1998).

\section{Aims of performance assessment}

A critical examination of the literature identified key steps to a successful performance evaluation system; the results are shown in Table 3. 
Table 3

Evidence Map

\begin{tabular}{|c|c|c|c|c|c|c|c|c|c|c|c|}
\hline \multirow{2}{*}{$\begin{array}{l}\text { Evidence } \\
\text { source }\end{array}$} & \multicolumn{3}{|c|}{$\begin{array}{l}\text { Purpose } \\
\text { performance } \\
\text { evaluation }\end{array}$} & \multicolumn{6}{|c|}{ Core components of performance evaluation } & \multirow{2}{*}{ Tools } & \multirow[b]{2}{*}{ Barriers } \\
\hline & 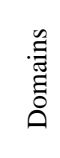 & 竞 & 尝 & 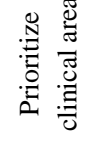 & 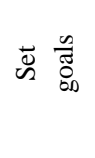 & 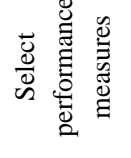 & 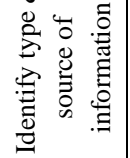 & 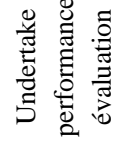 & 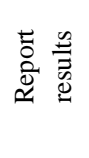 & & \\
\hline Adair et al. (2003) & $*$ & * & $*$ & & & & & & & & \\
\hline Arah et al. (2003) & & & $*$ & & & & & $*$ & & & \\
\hline $\begin{array}{lll}\text { Arnold } & \& & \text { Pulich } \\
(2003) & & \\
\end{array}$ & & & $*$ & & & $*$ & & * & & $*$ & $*$ \\
\hline Bannigan (2000) & & & & & & * & & & * & $*$ & \\
\hline Benté (2005) & & & & & & $*$ & & & & & \\
\hline $\begin{array}{lll}\text { Beyan } & \& & \text { Baykal } \\
(2012) & & \\
\end{array}$ & & & & & $*$ & $*$ & $*$ & & & & \\
\hline Bititci et al. (2011) & & * & & & * & & & & & & \\
\hline Bradley et al. (2004) & & & * & & & & & & & & \\
\hline \begin{tabular}{lll|}
$\begin{array}{l}\text { Bradley } \\
(2012)\end{array}$ & $\&$ & Yuan \\
\end{tabular} & & & & & & & & & & & * \\
\hline Campbell et al. (2000) & $*$ & & & & & & & & & & \\
\hline $\begin{array}{l}\text { Champagne et al. } \\
(2005)\end{array}$ & & & $*$ & & & & & & & & \\
\hline $\begin{array}{l}\begin{array}{l}\text { Chandra } \\
(2004)\end{array} \\
\end{array}$ & & & $*$ & & & $*$ & & $*$ & & * & $*$ \\
\hline Colton (2007) & & & & & & & & & $*$ & & \\
\hline Da silva et al. (2011) & $*$ & & & & & & & & & & \\
\hline $\begin{array}{l}\text { Adam \& de Savigny } \\
\text { (2012) }\end{array}$ & & & & & & & & & & & $*$ \\
\hline Derose \& Petiti (2003) & & & $*$ & & & * & * & & & & \\
\hline Devkaran (2014) & & & & & * & & & & $*$ & $*$ & \\
\hline Dieleman et al. (2006) & & & & & & & & & & & $*$ \\
\hline $\begin{array}{l}\text { Doherty \& DeWeaver } \\
(2004) .\end{array}$ & & & $*$ & & & & & $*$ & & & \\
\hline Figueras et al. (2008) & & & & & * & & $*$ & $*$ & $*$ & * & \\
\hline Geddes \& Gill (2012) & & & $*$ & & & $*$ & & & & * & * \\
\hline Geraedts et al. (2003) & & & & * & & * & * & $*$ & & & \\
\hline $\begin{array}{l}\text { Greenfield } \& \\
\text { Braithwaite (2008) }\end{array}$ & & & & & $*$ & & & $*$ & & $*$ & \\
\hline Gregory (2000) & & & $*$ & & & & & & & & \\
\hline Hamilton et al. (2007) & & & & & & $*$ & $*$ & & & $*$ & $*$ \\
\hline Harp (2004) & & & & & & & & & & $*$ & \\
\hline Wolfe (2001) & * & & & & & & & & & & \\
\hline Johansen et al. (2004) & & & & & & $*$ & & & & * & \\
\hline Jolley (2003) & & & $*$ & & & $*$ & $*$ & & & & \\
\hline 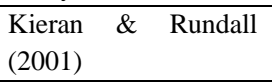 & & & & & & & & $*$ & & & \\
\hline $\begin{array}{lll}\begin{array}{l}\text { Kilbourne } \\
(2010)\end{array} & \text { et } & \text { al. } \\
\end{array}$ & & & & & & $*$ & $*$ & & & & \\
\hline Koch et al. (2011) & & & & & & & & & & $*$ & \\
\hline Kollberg et al. (2005) & & & $*$ & & & & & & & & $*$ \\
\hline Koss et al. (2002) & & & $*$ & & & & & & & & \\
\hline Kringos et al. (2010) & & & $*$ & & & & & & & & \\
\hline Loeb (2004) & & & & & * & * & & & & & $*$ \\
\hline Mainz (2003) & & & $*$ & & & $*$ & & & & & \\
\hline Manderscheid (2006) & & & $*$ & & & & & & & & \\
\hline $\begin{array}{l}\text { Mannion \& Goddard } \\
(2002)\end{array}$ & & & * & & * & $*$ & & & & & \\
\hline
\end{tabular}




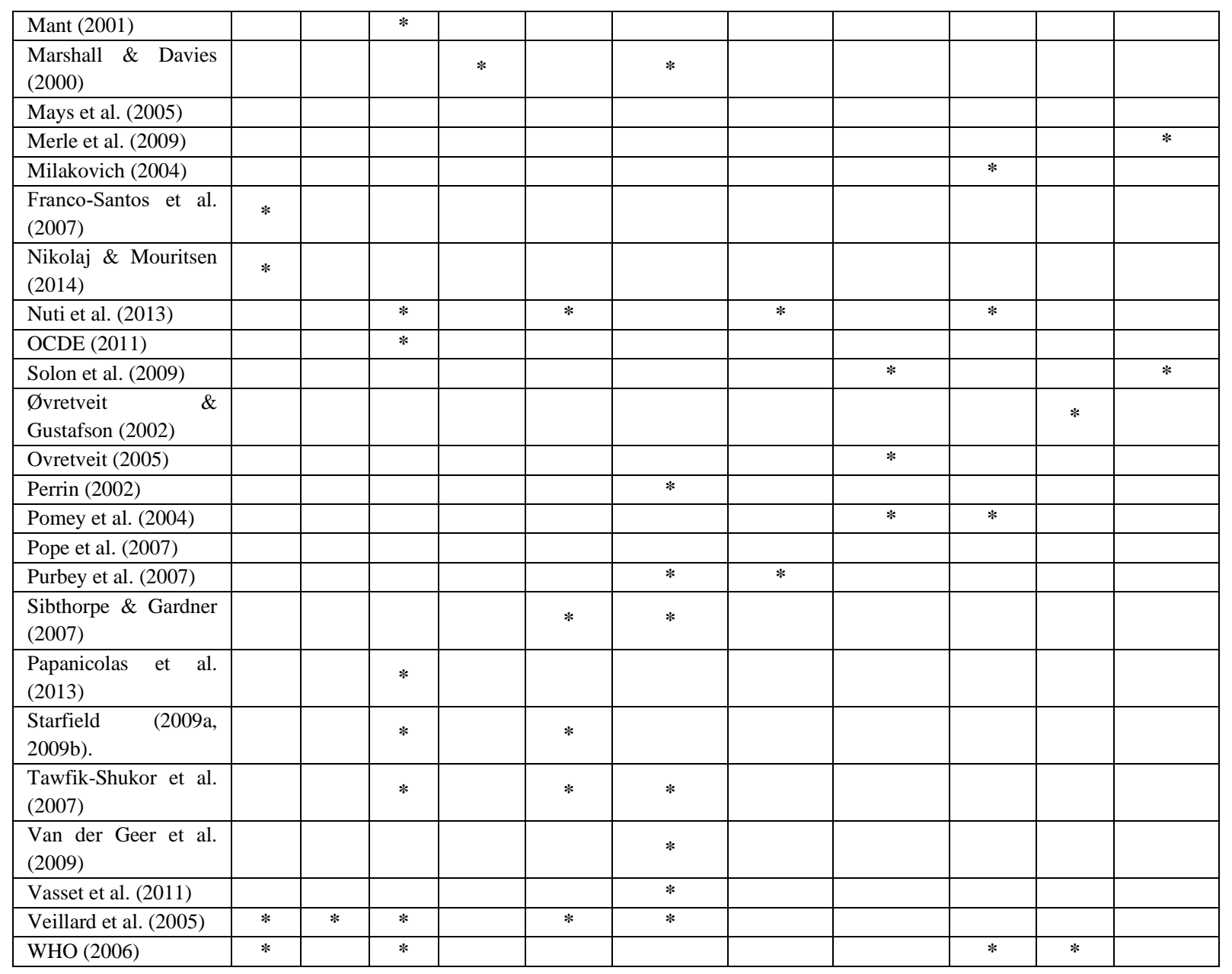

A comparison of the different performance measurement models according to the following variables: performance analysis angle; performance criteria; performance evaluation; outcomes; and performance measurement matrices shows that most models share a tendency toward the organizational performance, use structure, process, and outcomes, use indicators to measure the quality-of-care delivery and use feedback. However, almost everyone agrees on the non-universality of criteria and the need to consider the three levels of performance (individual, organizational, and collective). An organization must balance results, processes, and resources for being successful.

Table 4

Comparative Study of Some Models of Quality-of-Care Performance Measurement According to Certain Performance Criteria

\begin{tabular}{|l|l|l|l|l|l|}
\hline Framework & $\begin{array}{l}\text { Angle } \\
\text { Analysis } \\
\text { Performance }\end{array}$ & Performance Criteria & $\begin{array}{l}\text { Evaluation of the } \\
\text { Performance }\end{array}$ & $\begin{array}{l}\text { Résults } \\
\text { Measurement Matrices }\end{array}$ \\
\hline $\begin{array}{l}\text { Donabedian's } \\
\text { (1988) Model }\end{array}$ & $\begin{array}{l}\text { Global } \\
\text { Performance }\end{array}$ & $\begin{array}{l}\text { Structures, Processes, } \\
\text { Results as parameters of } \\
\text { quality of care. }\end{array}$ & $\begin{array}{l}\text { Indicators of } \\
\text { coherence, } \\
\text { relevance, } \\
\text { objectivity, } \\
\text { specificity, } \\
\text { variability. }\end{array}$ & $\begin{array}{l}\text { Non-universality of } \\
\text { criteria and taking into } \\
\text { account three levels of } \\
\text { performance } \\
\text { (individual, } \\
\text { organizational } \\
\text { collective) }\end{array}$ & $\begin{array}{l}\text { Ensure } \\
\text { between } \\
\text { processes. } \\
\text { results and }\end{array}$ \\
\hline $\begin{array}{l}\text { Sicotte et al.'s } \\
\text { (1998) Model }\end{array}$ & $\begin{array}{l}\text { organisational } \\
\text { Performance }\end{array}$ & $\begin{array}{l}\text { Alignment of four } \\
\text { organizational functions } \\
\text { (Adaptation Function, }\end{array}$ & $\begin{array}{l}\text { Performance criteria } \\
\text { are defined for each } \\
\text { function and for the }\end{array}$ & $\begin{array}{l}\text { Reading grid of the } \\
\text { organizational } \\
\text { performance }\end{array}$ & $\begin{array}{l}\text { Performance appraisal } \\
\text { is based on measuring } \\
\text { success indicators in }\end{array}$ \\
\hline
\end{tabular}




\begin{tabular}{|c|c|c|c|c|c|}
\hline & & $\begin{array}{lr}\text { Goal } & \text { Achievement } \\
\text { Function, } & \text { Production } \\
\text { Function, } & \text { Value } \\
\text { Maintenance } & \text { Function) }\end{array}$ & $\begin{array}{l}\text { alignment of } \\
\text { functions between } \\
\text { them. }\end{array}$ & & $\begin{array}{l}\text { each of the four } \\
\text { functions of the } \\
\text { organization. } \\
\text { The ability of the } \\
\text { government to } \\
\text { orchestrate and } \\
\text { exchanges } \\
\text { negotiations between } \\
\text { the four functions by } \\
\text { the different actors. }\end{array}$ \\
\hline $\begin{array}{ll}\text { Agarwal et } \\
\text { al.’s } \\
\text { Model }\end{array}$ & $\begin{array}{l}\text { Comparison } \\
\text { performance }\end{array}$ & & $\begin{array}{l}\text { Analysis of the } \\
\text { performance of } \\
\text { primary health care } \\
\text { structures using data } \\
\text { produced by } \\
\text { information systems. }\end{array}$ & $\begin{array}{l}\text { Analysis of the } \\
\text { performance of } \\
\text { primary health care } \\
\text { structures from the } \\
\text { point of view of care } \\
\text { providers and care } \\
\text { recipients. }\end{array}$ & $\begin{array}{l}\text { The comparison of the } \\
\text { performance } \\
\text { assessment measured } \\
\text { by the information } \\
\text { systems with the } \\
\text { assessment made by the } \\
\text { care providers and the } \\
\text { patients. }\end{array}$ \\
\hline $\begin{array}{l}\text { Starfield's } \\
\text { Model (2009) }\end{array}$ & $\begin{array}{l}\text { organisational } \\
\text { Performance }\end{array}$ & $\begin{array}{l}\text { Structures, Processes, } \\
\text { Results }\end{array}$ & $\begin{array}{l}\text { Indicators to } \\
\text { "measure" the } \\
\text { quality of care with a } \\
\text { credible, relevant, } \\
\text { objective and } \\
\text { transparent } \\
\text { measurement } \\
\text { system. }\end{array}$ & & $\begin{array}{l}\text { Included, structure } \\
\text { process and results }\end{array}$ \\
\hline
\end{tabular}

The principle of performance evaluation is to help health facilities identify problems or opportunities for improvement, recognize satisfactory performance, effective practices, develop strategies that can promote improvement, and achieve desired goals. There are many other reasons for undertaking performance evaluation, and they can be categorized based on the perspectives of different stakeholders. From a practitioner's point of view, performance evaluation can provide an effective tool for improving the quality of health care (Arnold \& Pulich, 2003; Chandra \& Frank, 2004; Geddes \& Gill, 2012; Gregory, 2000; Koss et al., 2002; Mant, 2001), it can also help to identify professional development needs (Geddes \& Gill, 2012). Performance evaluation enables the consumer to improve the care provided (Geddes \& Gill, 2012; Mainz, 2003; MSW et al., 2004). For senior personnel, managers or administrators, performance evaluation can meet accreditation standards and third-party contractual standards (Geddes \& Gill, 2012; Mainz, 2003). It can also facilitate leadership development and inform human resources decisions (Arnold \& Pulich, 2003; Chandra \& Frank, 2004; Geddes \& Gill, 2012). Finally, at the national level, performance evaluation data can inform policy-making and formulate strategies at a regional or national level (Geddes \& Gill, 2012). Several reasons are reported in the literature for undertaking performance evaluation, and for the majority of studies, performance evaluation indicates a measure of the quality of health care. Some articles explicitly reported about the purpose of performance evaluation in health care (Arnold \& Pulich, 2003; Chandra \& Frank, 2004; Derose \& Petitti, 2003; Geddes \& Gill, 2012; Gregory, 2000; Koss et al., 2002; Mainz, 2003; Manderscheid, 2006; Mant, 2001; Nuti et al., 2013; Tawfik-Shukor et al., 2007), obtaining an accurate insight about the quality of care and promoting improvement in terms of health service delivery (Derose \& Petitti, 2003; Jolley, 2003; Mainz, 2003; Manderscheid, 2006; Mant, 2001; Nuti et al., 2013; Tawfik-Shukor et al., 2007). Administration, operational and financial management has been identified as one of the 
key roles of performance evaluation (Jolley, 2003). The models target two main components: the service delivery of health care and the technical quality of the clinical care (OCDE, 2011), and serve two main objectives: improve the quality and the promotion of the responsibility (OCDE, 2011).

\section{Conceptual performance measures}

Several performance measurement frameworks were developed, which are based on a triad of the Donabedian model (Structure, Process, and outputs) and 'Institute Of Medicine,' and the 'WHO' domains; all of the frameworks target the efficiency and the effectiveness of their activities (Champagne et al., 2005). In addition, the quality improvement passes the possibility of revaluing and adjusting the strategies, the programs, the politics, and the associated objectives (Veillard et al., 2010). It is important to measure and evaluate the quality of prevention strategies for several reasons: 1) to better understand their operating mechanisms and their potential benefits and risks, 2) to measure their impact and their suitability, and 3) to evaluate their usefulness in reducing health inequalities (Starfield, 2009a). Four components are essential for quality front-line services: first-contact access for each need, long-term personfocused care, comprehensive care for most health needs, and coordinated care when it must be sought elsewhere (Starfield, 2009b). For each dimension, it is necessary to choose indicators to "measure" the quality-of-care delivery, a credible, relevant, objective, and transparent measurement system. A conceptual model of performance was elaborated to identify dimensions and sub-dimensions of performance (Veillard et al., 2005), but there are numerous challenges in carrying out international comparisons of health system performance, among which is the limited availability of comparable data (Papanicolas et al., 2013), a multidimensional approach to hospital performance: all dimensions are considered interdependent and are to be assessed simultaneously (Veillard et al., 2005). Several dimensions have been cited in the literature: Effectiveness, safety, responsiveness, accessibility, equity, efficiency, acceptability, appropriateness, competence or capability, continuity, timeliness, and sustainability (Papanicolas et al., 2013).

\section{Core Elements of a Performance Evaluation System Setting the goals for performance evaluation}

The main objective is the improvement of health care outcomes. The basic principle of good performance evaluation is the upfront development of strategic measurement goals (Loeb, 2004; Mannion et al., 2016; Sibthorpe \& Gardner, 2007). The goal of evaluation is typically targeted to improve the following domains: acceptability, accessibility, appropriateness, continuity, competency or capability, effectiveness, clinical focus, cost, efficiency, equity, governance, patient-centeredness, safety, sustainability, timeliness, and utilization (Beyan \& Baykal, 2012; Macinko et al., 2009; Nuti et al., 2013; Tawfik-Shukor et al., 200; Veillard et al., 2005). Performance evaluation targets all dimensions of quality and aims to meet the needs of stakeholders.

\section{Prioritizing clinical areas for performance evaluation}

Undertaking performance evaluation can be a laborious and time-consuming process; carefully selecting a clinical area for evaluation is very important. Therefore, several criteria are proposed 
in the literature to select the appropriate aspects of care for performance evaluation, namely: are important and relevant to the group for which the performance evaluation system is being produced (Geraedts et al., 2003); are problem-prone and with a high frequency of occurrence, or those suspected of overuse, underuse, or misuse(Geraedts et al., 2003; Mainz, 2003); have a strong financial impact (Geraedts et al., 2003; Mainz, 2003); the potential to improve health care delivery and outcomes (Geraedts et al., 2003; Mainz, 2003); recently undergone major (Geraedts et al., 2003); proven and significant variation in the quality of service among health care providers, or where there is evidence that the quality of service is suboptimal (Geraedts et al., 2003; Mainz, 2003); are considered high risk for patients (Geraedts et al., 2003).

\section{Selecting performance measures}

Performance measurement refers to a measure that can be used to monitor and evaluate the quality of important governance, clinical, and support functions that affect patient outcomes (Mainz, 2003). It measures the extent to which set goals or targets are achieved. Performance measure should correspond to one or more of the target dimensions or goals and is determined based on the level of the health system being evaluated, and can be developed from goals and objectives, which must meet the expectations of the individual and the strategic goals and organization (Arnold \& Pulich, 2003; Bourne et al., 2000; Chandra \& Frank, 2004; Geddes \& Gill, 2012; Jolley, 2003). The objectives must be assumed by the manager and the practitioner in order to give the opportunity to partners (Arnold \& Pulich, 2003). Performance measures should be linked to the strategic planning of the service and the overall organization values and standards (Jolley, 2003; Purbey et al., 2007). At the national level, performance measures should capture outcomes, which are broad in scope (Jolley, 2003). Performance measures are related to structure, process, and outcomes (Duncan \& Murray, 2012). These quality concepts have been reported in performance evaluation studies (Beyan \& Baykal, 2012; Derose \& Petitti, 2003; Johansen et al., 2004; Kilbourne et al., 2010; Mainz, 2003; Mannion et al., 2016; Perrin, 2002; Roper \& Mays, 2000; Sibthorpe \& Gardner, 2007; Tawfik-Shukor et al., 2007; van der Geer et al., 2009) Performance measures are based on standards of care determined by an expert from the panel of health care practitioners (Benté, 2005; Hamilton et al., 2007; Mainz, 2003). They must be clear, valid, reliable, reproducible, discriminative, easy to use Bannigan, 2000; Derose \& Petitti, 2003; Geraedts et al., 2003; Mainz, 2003; Marshall \& Davies, 2000; Purbey et al., 2007; Roper \& Mays, 2000; Vasset et al., 2011; Veillard et al., 2005), and should be comprehensive yet practically relevant and meaningful (Geddes \& Gill, 2012; Mainz, 2003). Multiple measures are favored over a single measure to obtain a comprehensive picture of health care (Loeb, 2004).

\section{Identifying types and sources of information}

Performance evaluation should obtain information or data from several perspectives, as this will provide a richer assessment of performance than a single source (Hamilton et al., 2007; Jolley, 2003; Kilbourne et al., 2010; Nuti et al., 2013; Purbey et al., 2007). This should involve representatives from specific stakeholder groups depending on the level of the health system being evaluated (Geraedts et al., 2003; Jolley, 2003). The source of information can be varied, such as information systems (reports, surveys, and records). Data types are usually categorized 
as clinical data, administrative data, and patient-based data (Beyan \& Baykal, 2012; Derose \& Petitti, 2003). Clinical data can be obtained from medical records, patient records, discharge reports, diagnostic reports. Administrative data is related to health expenses, including billing and claims. Patient information is collected directly from patients through questionnaires or interviews.

\section{Undertaking performance evaluation}

The objectives, procedures, participants, materials, and premises for performance evaluation should be clearly identified and documented (Geraedts et al., 2003). A schedule for performance evaluation that works well with the practice is recommended (O'Doherty et al., 2015). Evaluator training is also a key factor in effective performance evaluation (Arnold \& Pulich, 2003; Chandra \& Frank, 2004). Training has been reported to improve consistency and develop confidence evaluation instruments (Chandra \& Frank, 2004). All 'evaluators' or anyone completing the measurement must be instructed about the performance measurement process 'PMS' (Arnold \& Pulich, 2003). The use of a 'PMS' appears to be useful for organizational management from three perspectives: organizational purpose, stakeholder perspective, and management through consideration of financial sustainability, equity, efficiency, and effectiveness (Moura et al., 2020).

\section{Reporting of results}

The communication of results should be integrated into the performance assessment system (Bannigan, 2000; Nuti et al., 2013). Feedback to health practitioners and their organizations serves either as a recognition of good performance or as an improvement goal, which can affect service performance and provider motivation (Colton, 2007). Although the majority of data collected in health care facilities provide useful information, additional information can be obtained by comparing the results of other institutions. Norms and standards allow data to be compared to references (Sibthorpe \& Gardner, 2007).

\section{Tools for Evaluating Performance}

Nine articles (Arnold \& Pulich, 2003; Chandra \& Frank, 2004; Geddes \& Gill, 2012; Hamilton et al., 2007; Harp, 2004; Johansen et al., 2004; Koch et al., 2011; MSW et al., 2004; van der Geer et al., 2009) reported a wide range of tools for evaluation, often comprising the use of more than one instrument. The choice of tools depends on several factors, including the level of health, the objectives of the assessment, and the target population. An audit is a practiceoriented tool in which the performance data collected is compared to standards (Bannigan, 2000; Hamilton et al., 2007). These standards define the level of performance required to achieve work expectations and specify what the consumers can expect from the practitioners (Hamilton et al., 2007). Practitioner-focused tools consisted of the following: direct clinical observation of the clinician in the patient's setting (Chandra \& Frank, 2004; Doherty \& Deweaver, 2004; Geddes \& Gill, 2012), interview with the practitioner (Geddes \& Gill, 2012), critical incident reporting (Bannigan, 2000), self-reflection or self-appraisal (Geddes \& Gill, 2012), peer review or appraisal (Arnold \& Pulich, 2003; Bannigan, 2000; Chandra \& Frank, 2004), and chart-stimulated recall(Harp, 2004). Patient-focused tools include the use of outcome measures to collect information about patient health status (Duncan \& Murray, 2012; 
Johansen et al., 2004). Outcome measures are used to determine the evolution of the state of patients over time. They provide clinicians with feedback on patient outcomes, allow progress to be effectively communicated to patients, and promote treatment planning (Koch et al., 2011). Routine outcome measurement can also support or justify the interventions administered to patients and provide supporting evidence to funding bodies (Koch et al., 2011). In addition to the use of outcome measures is the use of patient satisfaction questionnaire (Bannigan, 2000), or patient reports (Koch et al., 2011), or actual complaints from clients (Bannigan, 2000). Koch et al.(2011) suggest that patient data may be used to demonstrate accountability, feedback to the individual practitioners, staff supervision, meet accreditation requirements, enhance staff morale, and support budget requests.

\section{Barriers to Performance Evaluation Implementation}

Although performance evaluation has significant benefits, the literature has also highlighted the obstacles and challenges of its implementation. Findings from seven articles (Arnold \& Pulich, 2003; Chandra \& Frank, 2004; Geddes \& Gill, 2012; Hamilton et al., 2007; Kollberg et al., 2005; Loeb, 2004; Sibthorpe \& Gardner, 2007) described these barriers and. The time required (Geddes \& Gill, 2012), cost associated (Chandra \& Frank, 2004; Hamilton et al., 2007; Loeb, 2004), and undertaking performance evaluation were reported as significant barriers. The time and workforce needed to support performance evaluation may be constrained by a health care financial system that places limitations on reimbursements (Sibthorpe \& Gardner, 2007). Personality conflict between managers and individual practitioners was identified as a major impediment to performance evaluation (Arnold \& Pulich, 2003; Geddes \& Gill, 2012). There is also resistance from professionals to the validity and usefulness of performance evaluation data. Difficulty in motivating personnel and managers of health departments was also raised as an important barrier to performance evaluation (Kollberg et al., 2005).

\section{Discussion}

Evaluating the quality of care poses several conceptual and practical challenges. It requires an evidence base that can be used to evaluate interventions (Hanefeld et al., 2017). Among the main models for measuring quality performance in the international community are the Donabedian model, the Institute of Medicine, and the 'WHO.' The dimensions of accessibility, efficiency, equity, patient-centeredness, and safety are used with a percentage higher than 50\% of the cases. In comparison, the dimensions of effectiveness and equity are used by $100 \%$ of the referential frameworks. Health system researchers have used a variety of terms to categorize health care performance indicators, but few frameworks have a theoretical, conceptual basis (Levesque \& Sutherland, 2020). According to Bennett and Peters (2015), national health systems assessments (HSA) should meet the following criteria: Relevance, trustworthiness in terms of being of high quality, rigorous and credible in the eyes of stakeholders, coherence, considering the health system as a meaningful whole with linkages across system components. Most of the frameworks cited in this paper were constructed with different aims. For example, the Integrated Performance Model for the Health care System frameworks was constructed to provide conceptually sound performance models based on theory (Champagne et al., 2005). The World Health Organization (WHO, 2000) and OECD (Arah et al., 2006) frameworks were created to facilitate performance measurement and evaluation efforts. The Systems Thinking to 
Improve the Public's Health (Leischow et al., 2008) frameworks were constructed to evaluate specific health system reforms. While the purposes of these frameworks may differ, all frameworks go about achieving their ends by attempting to provide conceptual clarity in analytical, technical, and operational thinking for the different stakeholders involved (Papanicolas et al., 2013). From the literature review of the characteristics and determinants of high-performing Health Care systems "HCS," we identified several key elements of strong "HCS". More than a package of services, "HCS" has four core functions: comprehensiveness of promoting, preventive, curative, and palliative care services; continuity across the life cycle; coordination across service providers and levels of the health care system; and a point of first contact access for the majority of patients' health needs (Veillard et al., 2017). First articulated by Starfield, these core functions have been broadly accepted by and included in all "HCS" frameworks. The influential work on quality of care by Donabedian, which emphasizes interactions among patients, providers, and communities as fundamental to quality, is also reflected in many models of health system performance (Veillard et al., 2017).

Performance is an ambiguous concept (Bukh \& Mouritsen, 2014); it is ambiguous and holds different potentialities for different stakeholders (van Dooren \& Thijs., 2010). Establishing an effective performance appraisal system is challenging for most organizations, and so is the search for best practice solutions for this core function. While several characteristics for effective performance measurement systems are identified, determining the objectives and key performance indicators to help an organization implement its strategy remains the starting point. Therefore, most definitions of quality are similar, except that sometimes, the acceptability, sustainability, and patients' experience are added (Da Silva et al., 2011). The process of quality improvement is not only beneficial for the system of care, but a good evaluation was recognized as a fundamental element for the improvement of the practices (Bradley et al., 2004). According to Starfield (2009a), the importance of measuring the quality of the prevention strategies helps 1) for better encircling of their operating mechanisms as well as their advantages and potential risks, 2) to measure their impact and their degree of adequacy, and 3) to estimate their utility with regard to the reduction of the disparities of health. Bradley and Yuan (2012) reported that if certain countries failed to reach their goals, others were successful. Other studies showed that the health systems of the low-income countries show weaknesses in the performance; however, lift multiple challenges which can be included under five major themes: leadership and governance, organization, sanitary information, financing, and human and material resources (Adam \& de Savigny, 2012). Bourne et al. (2003) concluded that the performance measurement literature is at the stage of identifying difficulties and pitfalls to be avoided based on practitioner experience with few published research studies. The recognition of the efforts was indicated as factors of valuation and motivation affecting the durability of the performance at the healthcare professionals (Dieleman et al., 2006), the comparison of the performances between hospitals seems to be associated with an improvement of the procedures of care (Merle et al., 2009). However, participation in competitions with the aim of winning a prize can represent an incentive for the professionals to improve their procedures and services (Milakovich, 2004). However, performance measures can be difficult, expensive, and controversial for developing countries (WHO, 2006). The value of performance measures is diminished by questions of motive, intention, and agenda (Solon et al., 2009). 
Health system performance assessments include quality of care as a key measure of system performance (Arah et al., 2003; Solon et al., 2009). According to Arah et al. (2006), a good conceptual framework is particularly essential when there are societal requirements for fairness, transparency, accountability, performance attribution, and rewarding of excellence. Several studies were interested in the search on the efficiency of the certification and the measure of performance (Greenfield \& Braithwaite, 2008; Ovretveit, 2005; Pomey et al., 2004; Walshe \& Rundall, 2001). Other studies explored the impact of these programs on the accredited bodies Devkaran, 2014; Pomey et al., 2004). Others tried to analyze the performance of the certification by examining their structure and their process (Devkaran, 2014; Greenfield \& Braithwaite, 2008), which shows the complexity of the problem and not the unification of the methods of research on the health care quality and the performance measurement. Performance management consists of the formulation of performance objectives, the establishment of enhancement strategies, evaluations regarding the infringement of these objectives, individual performance measures, and feedback systems (Bititci et al., 2011). The existing research does not contain a rigorous and thorough analysis of the conceptual frameworks and their relation with the performance results, the quality improvement, and the safety of the patients (Greenfield \& Braithwaite, 2008). Øvretveit and Gustafson (2002) revealed that the document retrieval contained relatively few proofs concerning the global efficiency of the quality interventions and the quality standards in health care. Accreditation bodies have developed clinical quality indicators in health care organizations. Consequently, improvements were apparently observed in the results of these organizations regarding care on the infrastructure and the performance of control of the infections of hospitals (Devkaran, 2014). The relevant results for the health care systems are bound to the health, to the equity, to patient satisfaction and the persons receiving benefits, to the costs, and to efficiency, the studies revealed links with governance, access, continuity, coordination, efficiency, and the strong primary care (Kringos et al., 2010). Within the framework of health care, the same advantages are brought back between the conceptual frameworks: 1) a better-quality control by the achievement of a minimum quality level of the service. 2) A better regulation by respecting the legal rules and of safety. 3) The continuous and long-lasting improvement of the quality. 4) The supply of information to the patients, which confers confidence in the supplied services and allows them to make informed decisions. 5) To establish a positive image insists on the aspects of practice and service standards in the primary health care centers (Buetow \& Wellingham, 2003). There are divergent and contradictory opinions as to the incidence of quality approaches on customer satisfaction. Performance measurement of quality of care remains far from having an effective measurement system for several reasons: the definition of objectives still poses problems, the results of measurement approaches are inconsistent, complex and unstable, and important challenges encountered: the epidemiological transition, the decentralization of the health system and insufficient funding (Zaadoud et al., 2020). The implementation of a transparent performance measure at every level of the health system, with a narrow correspondence between the objectives of intervention, followed the results such as appropriate indicators of progress, impact, and the measures, which take into account elements of performance susceptible to be managed by the direction. 


\section{Conclusion}

Measuring the performance of quality of care remains very difficult because of the lack of a valid framework and the insufficient mastery of the use of tools to improve health care quality. The 'CQI' approaches are a good tool to improve the quality of care. Even if the links are not established within the framework of scientific research, quality approaches are generally recognized as essential tools to help establishments improve the quality and safety of the patients. Conceptual frameworks proposed in quality approaches remain an essential lever for the promotion of quality approaches. However, the current approach regarding measuring the performance of quality is far from establishing an effective national system of performance measurement and production of reports for the following reasons. First, the objectives are not well defined and are not accessible. Second, the existing approaches produce measures, which are inconsistent, complex, and unstable, imposing to the persons receiving benefits of care the uncertainty and the burden of the contradictory measures. Third, the health care system also faces certain important challenges, including the epidemiological transition in chronic diseases, the decentralization of the health system, and the erosion of health financing.

\section{Limits}

Limitations of this study include: 1) lack of comprehensiveness compared to existing frameworks, 2) difficulty in assessing the reliability and validity of qualitative studies, 3) frameworks are not health system-specific, and (4) difficulty in the comparability of performance levels across countries.

\section{Practical Implications}

This study provides an analysis of the different conceptual frameworks for measuring the quality-of-care performance and a comparison between the different conceptual frameworks.

\section{References}

Adair, C. E., Simpson, L., Birdsell, J. M., Omelchuk, K., Casebeer, A. L., Gardiner, H. P., ... \& Beausejour, P. (2003). Performance measurement systems in health and mental health services: Models, practices and effectiveness. A state of the science review. The Alberta Heritage Foundation for Medical Research.

Adam, T., \& de Savigny, D. (2012). Systems thinking for strengthening health systems in LMICs: need for a paradigm shift. Health policy and planning, 27(suppl_4), iv1-iv3.

Agarwal, S., Sripad, P., Johnson, C., Kirk, K., Bellows, B., Ana, J., ... \& Warren, C. E. (2019). A conceptual framework for measuring community health workforce performance within primary health care systems. Human Resources For Health, 17(1), 1-20.

Arah, O. A., Custers, T., \& Klazinga, N. S. (2003). Updating the key dimensions of hospital performance: The move towards a theoretical framework. In Third WHO Workshop on Hospital Performance Measurement, Barcelona, 13-14.

Arah, O. A., Klazinga, N. S., Delnoij, D. M. J., Asbroek, A. H. A. T., \& Custers, T. (2003). Conceptual frameworks for health systems performance: A quest for effectiveness, quality, and improvement. International Journal for Quality in Health Care, 15(5), 377-398.

Arah, O. A., Westert, G. P., Hurst, J., \& Klazinga, N. S. (2006). A conceptual framework for the OECD health care quality indicators project. International Journal for Quality in Health Care, 18(suppl_1), 5-13. https://doi.org/10.1093/intqhe/mzl024 
Arnold, E., \& Pulich, M. (2003). Personality conflicts and objectivity in appraising performance. The Health Care Manager, 22(3), 227-232.

Bailie, R., Sibthorpe, B., Gardner, K., \& Si, D. (2008). Quality improvement in Indigenous primary health care : History, current initiatives and future directors. Australian Journal of Primary Health, 14(2), 53-57. https://doi.org/10.1071/py08022

Bannigan, K. (2000). To serve better: Addressing poor performance in occupational therapy. British Journal of Occupational Therapy, 63(11), 523-528. https://doi.org/10.1177/030802260006301103

Barbazza, E., Kringos, D., Kruse, I., Klazinga, N. S., \& Tello, J. E. (2019). Creating performance intelligence for primary health care strengthening in Europe. BMC Health Services Research, 19(1), 1-16. https://doi.org/10.1186/s12913-019$4853-\mathrm{z}$

Bennett, S., \& Peters, D. H. (2015). Assessing national health systems: Why and how. Health Systems \& Reform, 1(1), 9-17. https://doi.org/10.1080/23288604.2014.997107

Benté, J. R. (2005). Performance measurement, health care policy, and implications for rehabilitation services. Rehabilitation Psychology, 50(1), 87-93. https://doi.org/10.1037/0090-5550.50.1.87

Berman, P., \& Bitran, R. (2011). Health systems analysis for better health system strengthening. World Bank, https://openknowledge.worldbank.org/handle/10986/13593

Berwick, D. M. (2004). Lessons from developing nations on improving health care. BMJ, 328(7448), $1124-1129$. https://doi.org/10.1136/bmj.328.7448.1124

Beyan, O. D., \& Baykal, N. (2012). A knowledge based search tool for performance measures in health care systems. Journal of Medical Systems, 36(1), 201-221. https://doi.org/10.1007/s10916-010-9459-2

Bititci, U. S., Ackermann, F., Ates, A., Davies, J., Garengo, P., Gibb, S., MacBryde, J., Mackay, D., Maguire, C., van der Meer, R., Shafti, F., Bourne, M., \& Umit Firat, S. (2011). Managerial processes: Business process that sustain performance. International Journal of Operations \& Production Management, 31(8), 851-891. https://doi.org/10.1108/01443571111153076

Bititci, U. S., Turner, Ut., \& Begemann, C. (2000). Dynamics of performance measurement systems. International Journal of Operations \& Production Management, 20(6), 692-704. https://doi.org/10.1108/01443570010321676

Bouckaert, G., \& Van Dooren, W. (2015). Performance measurement and management in public sector organizations. Public Management and Governance, 174-187. Routledge. https://doi.org/10.4324/9781315693279-23

Bourne, M., Mills, J., Wilcox, M., Neely, A., \& Platts, K. (2000). Designing, implementing and updating performance measurement systems. International Journal of Operations \& Production Management, 20(7), 754-771. https://doi.org/10.1108/01443570010330739

Bourne, M., Neely, A., Mills, J., \& Platts, K. (2003). Implementing performance measurement systems: A literature review. International Journal of Business Performance Management, 5(1), 1-24. https://doi.org/10.1504/IJBPM.2003.002097

Bradley, E. H., \& Yuan, C. T. (2012). Quality of care in low- and middle-income settings: What next? International Journal for Quality in Health Care, 24(6), 547-549. https://doi.org/10.1093/intqhe/mzs065

Bradley, E. H., Holmboe, E. S., Mattera, J. A., Roumanis, S. A., Radford, M. J., \& Krumholz, H. M. (2004). Data feedback efforts in quality improvement: Lessons learned from US hospitals. BMJ Quality \& Safety, 13(1), 26-31. https://doi.org/10.1136/qshc.2002.4408

Braithwaite, J., Hibbert, P., Blakely, B., Plumb, J., Hannaford, N., Long, J. C., \& Marks, D. (2017). Health system frameworks and performance indicators in eight countries: A comparative international analysis. SAGE Open Medicine. https://doi.org/10.1177/2050312116686516

Buetow, S. A., \& Wellingham, J. (2003). Accreditation of general practices : Challenges and lessons. BMJ Quality \& Safety, 12(2), 129-135. https://doi.org/10.1136/qhc.12.2.129

Bukh, P. N., \& Mouritsen, J. (2014). Performance management. Danish Journal of Management \& Business, 3, 3-10.

Campbell, S. M., Roland, M. O., \& Buetow, S. A. (2000). Defining quality of care. Social Science \& Medicine, 51(11), 16111625. https://doi.org/10.1016/S0277-9536(00)00057-5

Champagne, F., Contandriopoulos, A. P., Picot-Touché, J., Beland, F., \& Nguyen, H. (2005). Un cadre d'évaluation de la performance des systèmes de services de santé : Le modèle EGIPSS [A framework for evaluating the performance of health service systems: The EGIPSS model]. Rapport de recherche, Groupe de recherche interdisciplinaire en santé Université de Montréal.

Chandra, A., \& Frank, Z. D. (2004). Utilization of performance appraisal systems in health care organizations and improvement strategies for supervisors. The Health Care Manager, 23(1), 25-30. 
Colton, D. (2007). Strategies for implementing performance measurement in behavioural health care organisations. Journal of Health Management, 9(3), 301-316. https://doi.org/10.1177/097206340700900301

Craig, P., Dieppe, P., Macintyre, S., Michie, S., Nazareth, I., \& Petticrew, M. (2013). Developing and evaluating complex interventions: The new medical research council guidance. International Journal of Nursing Studies, 50(5), 587-592. https://doi.org/10.1016/j.ijnurstu.2012.09.010

Da Silva, R. B., Contandriopoulos, A. P., Pineault, R., \& Tousignant, P. (2011). A global approach to evaluation of health services utilization: Concepts and measures. Healthcare Policy, 6(4), e106-e117.

Derose, S. F., \& Petitti, D. B. (2003). Measuring quality of care and performance from a population health care perspective. Annual Review of Public Health, 24(1), 363-384. https://doi.org/10.1146/annurev.publhealth.24.100901.140847

Devkaran, S. (2014). International healthcare accreditation: An analysis of clinical quality and patient experience in the UAE [Unpublished master's thesis]. Heriot-Watt University. https://www.ros.hw.ac.uk/handle/10399/2796

Dieleman, M., Toonen, J., Touré, H., \& Martineau, T. (2006). The match between motivation and performance management of health sector workers in Mali. Human Resources for Health, 4(1), 2. https://doi.org/10.1186/1478-4491-4-2

Doherty, J. B., \& Deweaver, K. L. (2004). A survey of evaluation practices for hospice social workers. Home Health Care Services Quarterly, 23(4), 1-13. https://doi.org/10.1300/J027v23n04_01

Donabedian, A. (1988). The quality of care how can it be assessed? JAMA.

Duncan, E. A. S., \& Murray, J. (2012). The barriers and facilitators to routine outcome measurement by allied health professionals in practice: A systematic review. BMC Health Services Research, 12, 96. https://doi.org/10.1186/1472-6963$12-96$

Elg, M., Palmberg Broryd, K., \& Kollberg, B. (2013). Performance measurement to drive improvements in healthcare practice. International Journal of Operations \& Production Management, 33(11/12), 1623-1651. https://doi.org/10.1108/IJOPM-07-2010-0208

Evans, D., \& FitzGerald, M. (2002). Reasons for physically restraining patients and residents: A systematic review and content analysis. International Journal of Nursing Studies, 39(7), 735-743. https://doi.org/10.1016/S00207489(02)00015-9

Figueras, F., Meler, E., Iraola, A., Eixarch, E., Coll, O., Figueras, J., Francis, A., Gratacos, E., \& Gardosi, J. (2008). Customized birthweight standards for a Spanish population. European Journal of Obstetrics \& Gynecology and Reproductive Biology, 136(1), 20-24. https://doi.org/10.1016/j.ejogrb.2006.12.015

Footman, K., Roberts, B., Mills, A., Richardson, E., \& McKee, M. (2013). Public satisfaction as a measure of health system performance: A study of nine countries in the former Soviet Union. Health Policy, 112(1), 62-69. https://doi.org/10.1016/j.healthpol.2013.03.004

Franco-Santos, M., Kennerley, M., Micheli, P., Martinez, V., Mason, S., Marr, B., ... \& Neely, A. (2007). Towards a definition of a business performance measurement system. International Journal of Operations \& Production Management, 27(8), 784-801. https://doi.org/10.1108/01443570710763778

Franco-Santos, M., Lucianetti, L., \& Bourne, M. (2012). Contemporary performance measurement systems: A review of their consequences and a framework for research. Management Accounting Research, 23(2), 79-119.

Geddes, E., \& Gill, C. (2012). Annual performance appraisal: One organization's process and retrospective analysis of outcomes. Healthcare Quarterly, 15(1), 59-63. https://doi.org/10.12927/hcq.2012.22764

Geraedts, M., Selbmann, H. K., \& Ollenshlaeger, G. (2003). Critical appraisal of clinical performance measures in Germany. International Journal for Quality in Health Care, 15(1), 79-085. https://doi.org/10.1093/intqhe/15.1.79

Greenfield, D., \& Braithwaite, J. (2008). Health sector accreditation research: A systematic review. Journal of the International Society for Quality in Health Care, 20(3), 172-183. https://doi.org/10.1093/intqhe/mzn005

Gregory, R. J. (2000). Performance appraisal: A primer for the lower level health care and rehabilitation worker. Journal of Health and Human Services Administration, 22(3), 374-378.

Grimmer, K., Lizarondo, L., Kumar, S., Bell, E., Buist, M., \& Weinstein, P. (2014). An evidence-based framework to measure quality of allied health care. Health Research Policy and Systems, 12(1), 1-10. https://doi.org/10.1186/1478-4505-12-10

Grimmer-Somers, K., Kumar, S., \& Milanese, S. (2012). Measuring the quality of allied health services in Australia: Is it a case of the 'more we learn, the less we know. Journal of Healthcare Leadership, 4, 71-81.

Groene, O., Botje, D., Suñol, R., Lopez, M. A., \& Wagner, C. (2013). A systematic review of instruments that assess the implementation of hospital quality management systems. International Journal for Quality in Health Care, 25(5), 525541. https://doi.org/10.1093/intqhc/mzt058 
Hamilton, K. E. S., Coates, V., Kelly, B., Boore, J. R. P., Cundell, J. H., Gracey, J., Mcfetridge, B., Mcgonigle, M., \& Sinclair, M. (2007). Performance assessment in health care providers: A critical review of evidence and current practice. Journal of Nursing Management, 15(8), 773-791. https://doi.org/10.1111/j.1365-2934.2007.00780.x

Hanefeld, J., Powell-Jackson, T., \& Balabanova, D. (2017). Understanding and measuring quality of care: Dealing with complexity. Bulletin of the World Health Organization, 95(5), 368.

Harp, S. S. (2004). The measurement of performance in a physical therapy clinical program. A ROI approach. The Health Care Manager, 23(2), 110-119. https://doi.org/10.1097/00126450-200404000-00003

Hogg, W., Rowan, M., Russell, G., Geneau, R., \& Muldoon, L. (2008). Framework for primary care organizations : The importance of a structural domain. International Journal for Quality in Health Care, 20(5), 308-313. https://doi.org/10.1093/intqhe/mzm054

Institute of Medicine (US) Committee on Quality of Health Care in America. (2001). Crossing the Quality Chasm : A New Health System for the 21st Century. National Academies Press (US). http://www.ncbi.nlm.nih.gov/books/NBK222274/

Jahanmehr, N., Rashidian, A., Khosravi, A., Farzadfar, F., Shariati, M., Majdzadeh, R., Sari, A. A., \& Mesdaghinia, A. (2015). A conceptual framework for evaluation of public health and primary care system performance in Iran. Global Journal of Health Science, 7(4), 341-357. https://doi.org/10.5539/gjhs.v7n4p341

Johansen, B., Mainz, J., Sabroe, S., Manniche, C., \& Leboeuf-Yde, C. (2004). Quality improvement in an outpatient department for subacute low back pain patients: Prospective surveillance by outcome and performance measures in a health technology assessment perspective. Spine, 29(8), 925-931. https://doi.org/10.1097/00007632-200404150-00021

Jolley, G. (2003). Performance measurement for community health services: Opportunities and challenges. Australian Health Review, 26(3), 133-138. https://doi.org/10.1071/ah030133

Kilbourne, A. M., Keyser, D., \& Pincus, H. A. (2010). Challenges and opportunities in measuring the quality of mental health care. Canadian Journal of Psychiatry. Revue Canadienne De Psychiatrie, 55(9), 549-557. https://doi.org/10.1177/070674371005500903

Koch, J. R., Breland, A. B., Nash, M., \& Cropsey, K. (2011). Assessing the utility of consumer surveys for improving the quality of behavioral health care services. The Journal of Behavioral Health Services \& Research, 38(2), $234-248$. https://doi.org/10.1007/s11414-010-9211-1

Kollberg, B., Elg, M., \& Lindmark, J. (2005). Design and implementation of a performance measurement system in Swedish health care services: A multiple case study of 6 development teams. Quality Management in Health Care, 14(2), 95-111. https://doi.org/10.1097/00019514-200504000-00005

Koss, R. G., Hanold, L. S., \& Loeb, J. M. (2002). Integrating healthcare standards and performance measurement. Disease Management and Health Outcomes, 10(2), 81-84. https://doi.org/10.2165/00115677-200210020-00002

Kringos, D. S., Boerma, W. G., Hutchinson, A., van der Zee, J., \& Groenewegen, P. P. (2010). The breadth of primary care : A systematic literature review of its core dimensions. BMC Health Services Research, 10(1), 1-13. https://doi.org/10.1186/1472-6963-10-65

Kruk, M., \& Freedman., L. P. (2008). Assessing health system performance in developing countries: A review of the literature. Health Policy, 85(2008), 263-276.

Langley, A., Bremond, M., \& Baker, G. R. (1998). A Conceptual framework for the analysis of health care organizations' performance. Health Services Management Research, 11(1), 24-41. https://doi.org/10.1177/095148489801100106

Lauer, J. A., Evans, D. B., \& Murray, C. J. (2003). Measuring health system attainment: the impact of variability in the importance of social goals. Health systems performance assessment: debates, methods and empiricism. Geneva: World Health Organization, 677-81.

Lauer, J. A., Lovell, C. K., Murray, C. J., \& Evans, D. B. (2004). World health system performance revisited : The impact of varying the relative importance of health system goals. BMC Health Services Research, 4(1), 19. https://doi.org/10.1186/1472-6963-4-19

Leischow, S. J., Best, A., Trochim, W. M., Clark, P. I., Gallagher, R. S., Marcus, S. E., \& Matthews, E. (2008). Systems thinking to improve the public's health. American Journal of Preventive Medicine, 35(2 0), S196-S203. https://doi.org/10.1016/j.amepre.2008.05.014

Levesque, J. F., \& Sutherland, K. (2020). Combining patient, clinical and system perspectives in assessing performance in healthcare: An integrated measurement framework. BMC Health Services Research, 20(1), 23. https://doi.org/10.1186/s12913-019-4807-5

Lizarondo, L., Grimmer, K., \& Kumar, S. (2014). Assisting allied health in performance evaluation: A systematic review. BMC Health Services Research, 14, 572. https://doi.org/10.1186/s12913-014-0572-7

Loeb, J. M. (2004). The current state of performance measurement in health care. International Journal for Quality in Health Care, 16(suppl_1), i5-i9. https://doi.org/10.1093/intqhe/mzh007 
Macinko, J., Starfield, B., \& Erinosho, T. (2009). The impact of primary healthcare on population health in low- and middleincome countries. The Journal of Ambulatory Care Management, 32(2), 150-171. https://doi.org/10.1097/JAC.0b013e3181994221

Mainz, J. (2003). Defining and classifying clinical indicators for quality improvement. International Journal for Quality in Health Care, 15(6), 523-530. https://doi.org/10.1093/intqhe/mzg081

Manderscheid, R. W. (2006). Some thoughts on the relationships between evidence based practices, practice based evidence, outcomes, and performance measures. ProQuest. https://search.proquest.com/openview/09115ddc74d51c34ef898f42cae56fe0/1 ?pq-origsite=gscholar\&cbl=38575

Mannion, R., Davies, H., \& Marshall, M. (2016). Impact of star performance ratings in English acute hospital trusts. Journal of Health Services Research \& Policy. https://doi.org/10.1177/135581960501000106

Mannion, R., \& Goddard, M. (2002). Performance measurement and improvement in health care. Applied Health Economics and Health Policy, 1(1), 13-23.

Mant, J. (2001). Process versus outcome indicators in the assessment of quality of health care. International Journal for Quality in Health Care, 13(6), 475-480. https://doi.org/10.1093/intqhe/13.6.475

Marshall, M. N., \& Davies, H. T. O. (2000). Performance measurement and management of healthcare professionals. Disease Management and Health Outcomes, 7(6), 305-314. https://doi.org/10.2165/00115677-200007060-00002

Mays, N., Pope, C., \& Popay, J. (2005). Systematically reviewing qualitative and quantitative evidence to inform management and policy-making in the health field. Journal of Health Services Research \& policy, 10(1_suppl), 6-20. https://journals.sagepub.com/doi/10.1258/1355819054308576

McCracken, M. J., McIlwain, T. F., \& Fottler, M. D. (2016). Measuring organizational performance in the hospital industry: An exploratory comparison of objective and subjective methods. Health Services Management Research. https://doi.org/10.1258/0951484011912717

Merle, V., Moret, L., Pidhorz, L., Dujardin, F., Gouin, F., Josset, V., Graveleau, S., Petit, J., Riou, F., Lombrail, P., \& Czernichow, P. (2009). Does comparison of performance lead to better care? A pilot observational study in patients admitted for hip fracture in three French public hospitals. International Journal for Quality in Health Care, 21(5), 321329. https://doi.org/10.1093/intqhe/mzp029

Milakovich, M. E. (2004). Rewarding quality and innovation: Awards, charters, and international standards as catalysts for change. In M. A. Wimmer (Éd.), knowledge management in electronic government (pp. 80-90). Springer. https://doi.org/10.1007/978-3-540-24683-1_9

Moura, L. F., Pinheiro de Lima, E., Deschamps, F., M. Van Aken, E., Gouvea Da Costa, S. E., Tavares Treintaa, F., Almeida Prado Cestari, J. M., \& Assumpção Silva, R. (2020). Factors for performance measurement systems design in nonprofit organizations and public administration. Measuring Business Excellence, 24(3), 377-399. https://doi.org/10.1108/MBE10-2019-0102

MSW, J. B. D., LCSW, MDiv, \& PhD, K. L. D. (2004). A Survey of evaluation practices for hospice social workers. Home Health Care Services Quarterly, 23(4), 1-13. https://doi.org/10.1300/J027v23n04_01

Murray, C. J., \& Frenk, J. (2000). A framework for assessing the performance of health systems. Bulletin of the world Health Organization, 78, 717-731.

National Academies of Sciences, Engineering, and Medicine. (2018). Crossing the global quality chasm : Improving health care worldwide. PubMed. https://doi.org/10.17226/25152

Neely, A., Gregory, M., \& Platts, K. (2005). Performance measurement system design : A literature review and research agenda. International Journal of Operations \& Production Management, 25(12), 1228-1263. https://doi.org/10.1108/01443570510633639

Nuti, S., Seghieri, C., \& Vainieri, M. (2013). Assessing the effectiveness of a performance evaluation system in the public health care sector: Some novel evidence from the Tuscany region experience. Journal of Management \& Governance, 17(1), 59-69. https://doi.org/10.1007/s10997-012-9218-5

OCDE. (2011). Improving health care performance: How to measure their quality. Éditions OCDE

O’Doherty, L., Hegarty, K., Ramsay, J., Davidson, L., Feder, G., \& Taft, A. (2015). Screening women for intimate partner violence in healthcare settings. Cochrane Database of Systematic Reviews, 7. https://doi.org/10.1002/14651858.CD007007.pub3

Ovretveit, J. (2005). Leading improvement. Journal of Health Organization and Management, 19(6), 413-430. https://doi.org/10.1108/14777260510629661

Øvretveit, J., \& Gustafson, D. (2002). Evaluation of quality improvement programmes. BMJ Quality \& Safety, 11(3), 270275. https://doi.org/10.1136/qhc.11.3.270 
Papanicolas, I., Kringos, D., Klazinga, N. S., \& Smith, P. C. (2013). Health system performance comparison: New directions in research and policy. Health Policy, 112(1), 1-3. https://doi.org/10.1016/j.healthpol.2013.07.018

Perrin, E. B. (2002). Some thoughts on outcomes research, quality improvement, and performance measurement. Medical Care, 40(6), III.

Piligrimienè, Ž., \& Bučiūnienè, I. (2008). Different perspectives on health care quality: Is the consensus possible? Engineering Economics, 56(1), Article 1. https://inzeko.ktu.lt/index.php/EE/article/view/11666

Pollitt, C. (2004). Performance management in practice: A comparative study of executive agencies. Journal of Public Administration Research and Theory, 16(1), 25-44. https://doi.org/10.1093/jopart/mui045.

Pomey, M. P., Contandriopoulos, A. P., François, P., \& Bertrand, D. (2004). Accreditation: A tool for organizational change in hospitals? International Journal of Health Care Quality Assurance Incorporating Leadership in Health Services, 17(23), 113-124. https://doi.org/10.1108/09526860410532757

Pope, C., Popay, J., \& Mays, N. (2007). Synthesizing qualitative and quantitative health evidence: A guide to methods. Maidenhead: Open University Press.

Purbey, S., Mukherjee, K., \& Bhar, C. (2007). Performance measurement system for healthcare processes. International Journal of Productivity and Performance Management, 56(3), 241-251. https://doi.org/10.1108/17410400710731446

Richardson, J., Wildman, J., \& Robertson, I. K. (2003). A critique of the World Health Organisation's evaluation of health system performance. Health Economics, 12(5), 355-366.

Roper, W. L., \& Mays, G. P. (2000). Performance measurement in public health: Conceptual and methodological issues in building the science base. Journal of Public Health Management and Practice, 6(5), 66-77.

Shortell, S. M., Schmittdiel, J., Wang, M. C., Li, R., Gillies, R. R., Casalino, L. P., Bodenheimer, T., \& Rundall, T. G. (2005). An empirical assessment of high-performing medical groups : Results from a national study. Medical Care Research and Review, 62(4), 407-434. https://doi.org/10.1177/1077558705277389

Sibthorpe, B. (2004). A proposed conceptual framework for performance assessment in primary health care: a tool for policy and practice. Australian Primary Health Care Research Institute. Retrieved March, 12, 2007.

Sibthorpe, B., \& Gardner, K. (2007). A conceptual framework for performance assessment in primary health care. Australian Journal of Primary Health, 13(2), 96-103. https://doi.org/10.1071/py07027

Sicotte, C., Champagne, F., Contandriopoulos, A. P., Barnsley, J., Beland, F., Leggat, S. G., Denis, J. L., Bilodeau, H.,

Snilstveit, B., Oliver, S., \& Vojtkova, M. (2012). Narrative approaches to systematic review and synthesis of evidence for international development policy and practice. Journal of Development Effectiveness, 4(3), 409-429. https://doi.org/10.1080/19439342.2012.710641

Solon, O., Woo, K., Quimbo, S. A., Shimkhada, R., Florentino, J., \& Peabody, J. W. (2009). A novel method for measuring health care system performance: Experience from QIDS in the Philippines. Health Policy and Planning, 24(3), 167-174. https://doi.org/10.1093/heapol/czp003

Starfield, B. (2009a). Primary care and equity in health: The importance to effectiveness and equity of responsiveness to peoples' needs. Humanity \& Society, 33(1-2), 56-73. https://doi.org/10.1177/016059760903300105

Starfield, B. (2009b). Toward international primary care reform. CMAJ, 180(11), $1091-1092$. https://doi.org/10.1503/cmaj.090542

Tawfik-Shukor, A. R., Klazinga, N. S., \& Arah, O. A. (2007). Comparing health system performance assessment and management approaches in the Netherlands and Ontario, Canada. BMC Health Services Research, 7(1), 25. https://doi.org/10.1186/1472-6963-7-25

van der Geer, E., van Tuijl, H. F. J. M., \& Rutte, C. G. (2009). Performance management in healthcare: Performance indicator development, task uncertainty, and types of performance indicators. Social Science \& Medicine, 69(10), 1523-1530. https://doi.org/10.1016/j.socscimed.2009.08.026

van Dooren, W., \& Thijs., N. (2010). Paradoxes of improving performance management (sytems) in public administration. EIPAScope, 2010(2), Article 2. http://www.eipa.eu/files/repository/eipascope/20101022101218_Eipascope_2010_2_Article2.pdf

Vasset, F., Marnburg, E., \& Furunes, T. (2011). The effects of performance appraisal in the Norwegian municipal health services: A case study. Human Resources for Health, 9, 22. https://doi.org/10.1186/1478-4491-9-22

Veillard, J., Champagne, F., Klazinga, N., Kazandjian, V., Arah, O. A., \& Guisset, A. L. (2005). A performance assessment framework for hospitals: The WHO regional office for Europe PATH project. International Journal for Quality in Health Care, 17(6), 487-496. https://doi.org/10.1093/intqhe/mzi072 
Veillard, J., Cowling, K., Bitton, A., Ratcliffe, H., Kimball, M., Barkley, S., Mercereau, L., Wong, E., Taylor, C., Hirschhorn, L. R., \& Wang, H. (2017). Better measurement for performance improvement in low- and middle-income countries: The Primary Health Care Performance Initiative (PHCPI) experience of conceptual framework development and indicator selection. The Milbank Quarterly, 95(4), 836-883. https://doi.org/10.1111/1468-0009.12301

Veillard, J., Garcia-Armesto, S., Kadandale, S., Klazinga, N., \& Leatherman, S. (2010). International health system comparisons: From measurement challenge to management tool. In P. C. Smith, E. Mossialos, \& I. Papanicolas (Éds.), Performance measurement for health system improvement (p. 641-672). Cambridge University Press. https://doi.org/10.1017/CBO9780511711800.023

Walshe, K., \& Rundall, T. G. (2001). Evidence-based management: From theory to practice in health care. The Milbank Quarterly, 79(3), 429-457, IV-V. https://doi.org/10.1111/1468-0009.00214

WHO (World Health Organization ). (2000). Health systems: Improving performance. The World health report. World Health Organization. https://apps.who.int/iris/handle/10665/42281

WHO (World Health Organization ). (2006). The performance assessment tool for quality improvement (path): Preparing for the second wave of data collection. Report on WHO workshop. WHO regional office for Europe. Barcelona.

Wolfe, A. (2001). Institute of medicine report: Crossing the quality Chasm: A new health care system for the 21 st century. Policy, Politics, \& Nursing Practice, 2(3), 233-235. https://doi.org/10.1177/152715440100200312

Zaadoud, B., Chbab, Y., \& Chaouch, A. (2020). Do performance measurement models have any impact on primary health care? A systematic review. International Journal of Health Governance, (ahead-of-print). https://doi.org/10.1108/IJHG04-2020-0039 


\section{Appendix A}

Characteristics of Studies Included in The Systematic Review

\begin{tabular}{|c|c|c|c|c|c|}
\hline & Author & Date & Theoretical & Title & Journal \\
\hline . & Bannigan & 2000 & & $\begin{array}{l}\text { To serve better: addressing poor performance in } \\
\text { occupational therapy. }\end{array}$ & $\begin{array}{l}\text { Br J Occup Ther, 63(11), } \\
523-528 .\end{array}$ \\
\hline 2. & Bititci et al. & 2000 & & \begin{tabular}{|l|} 
Dynamics of performance measurement systems. \\
\end{tabular} & $\begin{array}{l}\text { International Journal of } \\
\text { Operations \& Production } \\
\text { Management, 692-704 }\end{array}$ \\
\hline 3. & Gregory & 2000 & & $\begin{array}{l}\text { Performance appraisal: a primer for the lower-level } \\
\text { health care and rehabilitation worker }\end{array}$ & $\begin{array}{l}\text { J Health Hum Serv Adm, } \\
22(3), 374-378 .\end{array}$ \\
\hline t. & Marshall \& Davies & 2000 & & $\begin{array}{l}\text { Performance measurement and management of } \\
\text { healthcare professionals }\end{array}$ & $\begin{array}{l}\text { Dis Manage Health Out, } \\
7(6), 306-314 \text {. }\end{array}$ \\
\hline 5 . & Murray \& Frenk & 2000 & $\begin{array}{l}\text { Theme } \\
\text { Papers }\end{array}$ & $\begin{array}{l}\text { A framework for assessing the performance of health } \\
\text { systems. }\end{array}$ & $\begin{array}{l}\text { Bulletin of the World Health } \\
\text { Organization, 2000, 78(6) }\end{array}$ \\
\hline 5 . & Roper \& Mays & 2000 & & $\begin{array}{l}\text { Performance measurement in public health: conceptual } \\
\text { and methodological issues in building the science base. }\end{array}$ & $\begin{array}{l}\text { J Public Health Management } \\
\text { Practice, 6(5), 66-77. }\end{array}$ \\
\hline 7 . & Mant & 2001 & & $\begin{array}{l}\text { Process versus outcome indicators in the assessment of } \\
\text { quality of health care. }\end{array}$ & $\begin{array}{l}\text { Int J Qual Health C, 13(6), } \\
475-480 .\end{array}$ \\
\hline$\beta$. & Koss et al. & 2002 & & $\begin{array}{l}\text { Integrating healthcare standards and performance } \\
\text { measurement. }\end{array}$ & $\begin{array}{l}\text { Dis Manag Health Out, } \\
10(2), 81-84 .\end{array}$ \\
\hline . & Mannion \& Goddard & 2002 & & $\begin{array}{l}\text { Performance measurement and improvement in health } \\
\text { care. }\end{array}$ & $\begin{array}{l}\text { Appl Health Econ Health } \\
\text { Policy, 1(1), 13-23. }\end{array}$ \\
\hline 0 . & Øvretveit \& Gustafson & 2002 & Evaluation & Evaluation of quality improvement programmes. & $\begin{array}{l}\text { Qual Saf Health Care. Sep; } \\
11(3), 270-5 \text {. }\end{array}$ \\
\hline 1. & Perrin & 2002 & & $\begin{array}{l}\text { Some thoughts on outcomes research, quality } \\
\text { improvement, and performance measurement. }\end{array}$ & $\begin{array}{l}\text { Med Care, 40(6), IIII89- } \\
\text { III91. }\end{array}$ \\
\hline 2. & Adair et al. & 2003 & & $\begin{array}{l}\text { Performance Measurement Systems in Health and } \\
\text { Mental Health Services: Models, Practices and } \\
\text { Effectiveness A State of the Science Review. }\end{array}$ & $\begin{array}{l}\text { The Alberta Heritage } \\
\text { Foundation for Medical } \\
\text { Research. }\end{array}$ \\
\hline 3. & $\begin{array}{l}\text { Arah, Klazinga, Delnoij, } \\
\text { Asbroek, \& Custers }\end{array}$ & 2003 & & $\begin{array}{l}\text { Conceptual frameworks for health systems } \\
\text { performance: a quest for effectiveness, quality, and } \\
\text { improvement. }\end{array}$ & $\begin{array}{l}\text { International Journal for } \\
\text { Quality in Health Care, } \\
\text { 15(5) }\end{array}$ \\
\hline 4. & Arnold \& Pulich & 2003 & & $\begin{array}{l}\text { Personality conflicts and objectivity in appraising } \\
\text { performance. }\end{array}$ & $\begin{array}{l}\text { Health Care Manager, 22(3), } \\
227-232 .\end{array}$ \\
\hline 5. & Bourne et al. & 2000 & & $\begin{array}{l}\text { Designing, implementing and updating performance } \\
\text { measurement systems. }\end{array}$ & $\begin{array}{l}\text { International Journal of } \\
\text { Operations and Production } \\
\text { Management, 20(7), 754- } \\
771 .\end{array}$ \\
\hline 6. & Bourne et al. & 2003 & $\begin{array}{l}\text { Literature } \\
\text { review. }\end{array}$ & $\begin{array}{l}\text { Implementing performance measurement systems: a } \\
\text { literature review. }\end{array}$ & $\begin{array}{l}\text { Int. J. Business Performance } \\
\text { Management, 5(1), 1-24. }\end{array}$ \\
\hline 7. & Buetow & 2000 & & $\begin{array}{l}\text { accreditation of general practices:challenges and } \\
\text { lessons. }\end{array}$ & $\begin{array}{l}\text { Qual saf Health Care. Apr; } \\
12(2), 129-135 .\end{array}$ \\
\hline 8. & Derose \& Petitti & 2003 & & $\begin{array}{l}\text { Measuring quality of care and performance from a } \\
\text { population health care perspective. }\end{array}$ & $\begin{array}{l}\text { Annu Rev Publ Health, 24, } \\
\text { 363-384. }\end{array}$ \\
\hline 9. & Geraedts et al. & 2003 & & $\begin{array}{l}\text { Critical appraisal of clinical performance measures in } \\
\text { Germany. }\end{array}$ & $\begin{array}{l}\text { Int J Qual Health C, 15(1), } \\
79-85 .\end{array}$ \\
\hline 20. & Jolley & 2003 & & $\begin{array}{l}\text { Performance measurement for community health } \\
\text { services: opportunities and challenges. }\end{array}$ & $\begin{array}{l}\text { Aust Health Rev, 26(3), } \\
\text { 133-138. }\end{array}$ \\
\hline 21. & Lauer et al. & 2003 & A critique & $\begin{array}{l}\text { Measuring health system attainment: the impact of } \\
\text { variability in the importance of social goals. In Health } \\
\text { systems performance assessment: debates, methods and } \\
\text { empiricism. }\end{array}$ & $\begin{array}{l}\text { World Health Organization; } \\
677-81 . \text { Geneva }\end{array}$ \\
\hline
\end{tabular}




\begin{tabular}{|c|c|c|c|c|c|}
\hline 22. & Mainz & 2003 & & $\begin{array}{l}\text { Defining and classifying clinical indicators for quality } \\
\text { improvement. }\end{array}$ & $\begin{array}{l}\text { International Journal for } \\
\text { Quality in Health Care, } \\
15(6), 523-530 \text {, }\end{array}$ \\
\hline 3. & $\begin{array}{l}\text { Richardson, Wildman, } \\
\text { \& Robertson }\end{array}$ & 2003 & A critique & $\begin{array}{l}\text { A critique of the World Health Organisation's } \\
\text { evaluation of health system performance. }\end{array}$ & $\begin{array}{l}\text { Health Economic; 12, 355- } \\
66 .\end{array}$ \\
\hline 24. & Bradley et al. & 2004 & & $\begin{array}{l}\text { Data feedback efforts in quality improvement: lessons } \\
\text { learned from US hospitals. }\end{array}$ & $\begin{array}{l}\text { Quality and Safety in } \\
\text { Health Care, 26-31. }\end{array}$ \\
\hline 5. & Chandra \& Frank & 2004 & & $\begin{array}{l}\text { Utilization of performance appraisal systems in health } \\
\text { care organizations and improvement strategies for } \\
\text { supervisors }\end{array}$ & $\begin{array}{l}\text { Health Care Manager, 23(1), } \\
25-30 .\end{array}$ \\
\hline 26. & Harp & 2004 & & $\begin{array}{l}\text { The measurement of performance in a physical therapy } \\
\text { clinical program: a ROI approach. }\end{array}$ & $\begin{array}{l}\text { Health Care Manager, 23(2), } \\
110-119 .\end{array}$ \\
\hline 7. & $\begin{array}{l}\text { Lauer, Lovell, Murray, } \\
\& \text { Evans }\end{array}$ & 2004 & & $\begin{array}{l}\text { World Health System Performance revisited the impact } \\
\text { of varying the relative importance of health system } \\
\text { goals. }\end{array}$ & $\begin{array}{l}\text { BMC Health Services } \\
\text { Research } 2004 ; 4,19 .\end{array}$ \\
\hline 8. & Loeb & 2004 & & $\begin{array}{l}\text { The current state of performance measurement in health } \\
\text { care. }\end{array}$ & $\begin{array}{l}\text { Int J Qual Health C, } \\
\text { 16(supplement 1):i5-i9. }\end{array}$ \\
\hline 29. & Sibthorpe & 2004 & & $\begin{array}{l}\text { A Proposed Conceptual Framework for Performance } \\
\text { Assessment in Primary Health Care: a Tool for Policy } \\
\text { and Practice. }\end{array}$ & $\begin{array}{l}\text { Australian Primary Health } \\
\text { Care Research Institute. } \\
\text { Canberra }\end{array}$ \\
\hline 30. & Benté & 2005 & & $\begin{array}{l}\text { Performance measurement, health care policy, and } \\
\text { implications for rehabilitation services. }\end{array}$ & $\begin{array}{l}\text { Rehabil Psychol, 50(1), 87- } \\
93 .\end{array}$ \\
\hline$\beta 1$. & Kollberg et al. & 2005 & case study & $\begin{array}{l}\text { Design and implementation of a performance } \\
\text { measurement system in Swedish Health Care Services: } \\
\text { a multiple case study of } 6 \text { development teams }\end{array}$ & $\begin{array}{l}\text { Qual Manage Health Care, } \\
14(2), 95-111 .\end{array}$ \\
\hline$\beta 2$. & Mays et al. & 2005 & $\begin{array}{l}\text { Systematic } \\
\text { review }\end{array}$ & $\begin{array}{l}\text { Systematically reviewing qualitative and quantitative } \\
\text { evidence to inform management and policy making in } \\
\text { the health field. }\end{array}$ & $\begin{array}{l}\text { J Health Serv Res Policy, } \\
\text { 10(Supp11), 6-20. }\end{array}$ \\
\hline 33. & Neely et al. & 2005 & $\begin{array}{l}\text { literature } \\
\text { review }\end{array}$ & $\begin{array}{l}\text { Performance Measurement System Design: } \\
\text { a literature review and research agenda }\end{array}$ & $\begin{array}{l}\text { International Journal of } \\
\text { Operations \& Production } \\
\text { Management, 25(12). } \\
\end{array}$ \\
\hline 34. & Pollitt & 2004 & $\begin{array}{l}\text { comparative } \\
\text { study }\end{array}$ & $\begin{array}{l}\text { Performance management in practice: A comparative } \\
\text { study of executive agencies }\end{array}$ & $\begin{array}{lr}\text { Journal of } & \text { Public } \\
\text { Administration } & \text { Research } \\
\text { and Theory, 6(1), } 25-44 .\end{array}$ \\
\hline 35. & Shortell et al. & 2005 & Empirical & $\begin{array}{l}\text { An Empirical Assessment of High-Performing Medical } \\
\text { Groups: Results from a National Study. }\end{array}$ & $\begin{array}{l}\text { Medical Care Research and } \\
\text { Review, August 62(4), 407- } \\
34 .\end{array}$ \\
\hline 36. & Veillard et al. & 2005 & Project & $\begin{array}{l}\text { A performance assessment framework for hospitals: the } \\
\text { WHO regional office for Europe PATH project. }\end{array}$ & $\begin{array}{l}\text { Int J Qual C, 17(6), 487- } \\
496 .\end{array}$ \\
\hline 37. & Arah et al. & 2006 & project & $\begin{array}{l}\text { A conceptual framework for the OECD health care } \\
\text { quality indicators project. }\end{array}$ & $\begin{array}{l}\text { International Journal for } \\
\text { Quality in Health Care, } \\
\text { 18(5). }\end{array}$ \\
\hline$\beta 8$. & Dieleman et al. & 2006 & & $\begin{array}{l}\text { The match between motivation and performance } \\
\text { management of health sector workers in Mali. }\end{array}$ & $\begin{array}{l}\text { Human Resource for Health. } \\
4(2), 23-27 \text {. }\end{array}$ \\
\hline$\beta 9$. & Manderscheid & 2006 & & $\begin{array}{l}\text { Some thoughts on the relationships between evidence } \\
\text { based practices, practice based evidence, outcomes, and } \\
\text { performance measures. }\end{array}$ & $\begin{array}{l}\text { Adm Policy Ment Health, } \\
\text { 33, 646-647. }\end{array}$ \\
\hline 10. & Colton & 2007 & & $\begin{array}{l}\text { Strategies for implementing performance measurement } \\
\text { in behavioral health care organisations. }\end{array}$ & $\begin{array}{l}\text { J Health Manag, 9(3), 301- } \\
316 .\end{array}$ \\
\hline 41 . & Hamilton et al. & 2007 & $\begin{array}{l}\text { critical } \\
\text { review }\end{array}$ & $\begin{array}{l}\text { Performance assessment in healthcare providers: a } \\
\text { critical review of evidence and current practice. }\end{array}$ & J Nurs Manag, 15, 773-791. \\
\hline 12. & Purbey et al. & 2007 & & $\begin{array}{l}\text { Performance measurement system for healthcare } \\
\text { processes. }\end{array}$ & $\begin{array}{lr}\text { International Journal of } \\
\text { Productivity } \\
\text { Performance Management. }\end{array}$ \\
\hline 43. & Sibthorpe \& Gardner & 2007 & & $\begin{array}{l}\text { Conceptual Framework for Performance Assessment in } \\
\text { Primary Health Care. }\end{array}$ & $\begin{array}{lcr}\text { Australian } & \text { Journal of } \\
\text { Primary } & \text { Health; } 13(2), \\
\text { August. } & & \end{array}$ \\
\hline
\end{tabular}




\begin{tabular}{|c|c|c|c|c|c|}
\hline 14. & Tawfik-Shukor et al. & 2007 & Comparison & $\begin{array}{l}\text { Comparing Health System Performance Assessment } \\
\text { and Management approaches in the Netherlands and } \\
\text { Ontario. }\end{array}$ & $\begin{array}{l}\text { Canada BMC Health Serv } \\
\text { Res, } 7,25 .\end{array}$ \\
\hline 45. & $\begin{array}{l}\text { Bailie, Sibthorpe, \& } \\
\text { Gardner }\end{array}$ & 2008 & & $\begin{array}{l}\text { Quality improvement in Indigenous primary health } \\
\text { care: history, current initiatives and future directions. }\end{array}$ & $\begin{array}{l}\text { Australian Journal of } \\
\text { Primary Health } 14,53-57 .\end{array}$ \\
\hline 16. & $\begin{array}{l}\text { Greenfield } \\
\text { Braithwaite }\end{array}$ & 2008 & $\begin{array}{l}\text { systematic } \\
\text { review }\end{array}$ & $\begin{array}{l}\text { Health Sector Accreditation Research: a systematic } \\
\text { review. }\end{array}$ & $\begin{array}{l}\text { International Journal for } \\
\text { Quality in Health Care. } \\
20(3), 172-183 \text {. }\end{array}$ \\
\hline 47. & Hogg et al. & 2008 & & $\begin{array}{l}\text { Framework for primary care organizations: the } \\
\text { importance of a structural domain }\end{array}$ & $\begin{array}{l}\text { International Journal for } \\
\text { Quality in Health Care, } \\
20(5), 308-313\end{array}$ \\
\hline 48. & Kruk \& Freedman & 2008 & $\begin{array}{l}\text { review of the } \\
\text { literature }\end{array}$ & $\begin{array}{l}\text { Assessing health system performance in developing } \\
\text { countries: a review of the literature. }\end{array}$ & $\begin{array}{l}\text { Health Policy, Mar; 85(3), } \\
\text { 263-76. }\end{array}$ \\
\hline 49. & $\begin{array}{ll}\text { Piligrimienè } & \& \\
\text { Bučiūnienè } & \end{array}$ & 2008 & & $\begin{array}{l}\text { Different perspective on Health care quality Is the } \\
\text { consensus possible. }\end{array}$ & $\begin{array}{l}\text { Engineering Economics. No } \\
1 .\end{array}$ \\
\hline 50. & \begin{tabular}{lll|} 
Bouckaert & $\&$ & Van \\
Dooren & &
\end{tabular} & 2015 & & $\begin{array}{l}\text { Performance measurement and management in public } \\
\text { sector organizations. }\end{array}$ & $\begin{array}{l}\text { Public management and } \\
\text { governance }(2 \text { nd ed., pp. } \\
\text { 151-164). Abingdon: } \\
\text { Routledge. }\end{array}$ \\
\hline 1. & Merle et al. & 2009 & & Does comparison of performance lead to better care? & $\begin{array}{l}\text { International Journal of } \\
\text { Health Care Quality, 21(5), } \\
\text { 321-329. }\end{array}$ \\
\hline 2. & Solon et al. & 2009 & & $\begin{array}{l}\text { A novel method for measuring health care system } \\
\text { performance: experience from QIDS in the Philippines. }\end{array}$ & $\begin{array}{l}\text { Health Policy and Planning; } \\
24,167-174 \text {. }\end{array}$ \\
\hline 3. & Van der Geer et al. & 2009 & & $\begin{array}{l}\text { Performance management in healthcare: performance } \\
\text { indicator development, task uncertainty, and types of } \\
\text { performance indicators. }\end{array}$ & Soc Sci Med, 69,1523-1530. \\
\hline 54. & Kringos et al. & 2010 & $\begin{array}{l}\text { systematic } \\
\text { literature } \\
\text { review }\end{array}$ & $\begin{array}{l}\text { The breadth of primary care: a systematic literature } \\
\text { review of its core dimensions. }\end{array}$ & BMC HSR, 65-78. \\
\hline 55. & Berman \& Bitran & 2011 & $\begin{array}{l}\text { Discussion } \\
\text { Paper }\end{array}$ & $\begin{array}{l}\text { Health Systems Analysis for Better Health System } \\
\text { Strengthening }\end{array}$ & $\begin{array}{l}\text { The International Bank for } \\
\text { Reconstruction and } \\
\text { Development / The World } \\
\text { Ban }\end{array}$ \\
\hline 56. & Bititci et al. & 2011 & & $\begin{array}{l}\text { Managerial Processes: Business Process that Sustain } \\
\text { Performance. }\end{array}$ & $\begin{array}{l}\text { International Journal of } \\
\text { Operation and Production } \\
\text { Management, 31(8), 851- } \\
887 .\end{array}$ \\
\hline 57. & McCracken et al. & 2016 & & $\begin{array}{l}\text { Measuring organizational performance in the hospital } \\
\text { industry: An exploratory comparison of objective and } \\
\text { subjective methods }\end{array}$ & $\begin{array}{lr}\text { Health } & \text { Services } \\
\text { Management } & \text { Research, } \\
14(4), 211-219 . & \end{array}$ \\
\hline 88. & Beyan \& Baykal & 2012 & & $\begin{array}{l}\text { A knowledge based search tool for performance } \\
\text { measures in health care systems. }\end{array}$ & J Med Syst, 36, 201-221. \\
\hline$\$ 9$. & Snilstveit et al. & 2012 & & $\begin{array}{l}\text { Narrative approaches to systematic review and } \\
\text { synthesis of evidence for international development } \\
\text { policy and practice. }\end{array}$ & $\begin{array}{l}\text { Journal of Development } \\
\text { Effectiveness . 4, 409-429. }\end{array}$ \\
\hline 0. & Bradley \& Yuan & 2012 & & $\begin{array}{l}\text { Quality of care in low- and middle-income settings: } \\
\text { what next? }\end{array}$ & $\begin{array}{l}\text { International Journal of } \\
\text { Quality and Health Care. } \\
\text { 24(6), 547-549. }\end{array}$ \\
\hline 1. & Geddes \& Gill & 2012 & & $\begin{array}{l}\text { Annual performance appraisal: one organization's } \\
\text { process and retrospective analysis of outcomes. }\end{array}$ & Healthc Q, 15(1), 59-63. \\
\hline 2. & Grimmer-Somers et al. & 2012 & & $\begin{array}{l}\text { Measuring the quality of allied health services in } \\
\text { Australia: is it a case of the "more we learn, the less we } \\
\text { know? }\end{array}$ & J Healthc Leaders, 4, 71-81. \\
\hline$\$ 3$. & Franco-Santos et al. & 2012 & & $\begin{array}{l}\text { Contemporary performance measurement systems: A } \\
\text { review of their consequences and a framework for } \\
\text { research. }\end{array}$ & $\begin{array}{l}\text { Management Accounting } \\
\text { Research, 23(2), 79-19 }\end{array}$ \\
\hline 54. & Elg et al. & 2013 & & $\begin{array}{l}\text { Performance measurement to drive improvements in } \\
\text { healthcare practice. }\end{array}$ & $\begin{array}{l}\text { International Journal of } \\
\text { Operations and Production } \\
\text { Management, } 33(11 / 12), \\
\text { 1623-1651. }\end{array}$ \\
\hline
\end{tabular}




\begin{tabular}{|c|c|c|c|c|c|}
\hline 55. & Groene et al. & 2013 & $\begin{array}{l}\text { Systematic } \\
\text { review }\end{array}$ & $\begin{array}{l}\text { Systematic review of instruments that assess the } \\
\text { implementation of Hospital Quality Management } \\
\text { Systems. }\end{array}$ & $\begin{array}{l}\text { Int J Qual Health Care, } 525 \\
41 .\end{array}$ \\
\hline 56. & Footman et al. & 2013 & Comparison & $\begin{array}{l}\text { Public satisfaction as a measure of health system } \\
\text { performance: A study of nine countries in the former } \\
\text { Soviet Union. }\end{array}$ & Health Policy, $11262-69$ \\
\hline 57. & Nuti et al. & 2013 & & $\begin{array}{l}\text { Assessing the effectiveness of a performance } \\
\text { evaluation system in the public health care sector: } \\
\text { Some novel evidence from the Tuscany region } \\
\text { experience. }\end{array}$ & $\begin{array}{l}\text { Journal of Management and } \\
\text { Governance, 17(1), 59-69. }\end{array}$ \\
\hline 58. & Grimmer et al. & 2014 & & $\begin{array}{l}\text { An evidence-based framework to measure quality of } \\
\text { allied health care. }\end{array}$ & $\begin{array}{l}\text { Health Research Policy and } \\
\text { Systems. }\end{array}$ \\
\hline 59. & Jahanmehr et al. & 2015 & & $\begin{array}{l}\text { A Conceptual Framework for Evaluation of Public } \\
\text { Health and Primary Care System Performance in Iran. }\end{array}$ & $\begin{array}{l}\text { Global Journal of Health } \\
\text { Science; } 7(4) \text {. }\end{array}$ \\
\hline 70. & Braithwaite et al. & 2017 & comparison & $\begin{array}{l}\text { Health system frameworks and performance indicators } \\
\text { in eight countries: A comparative international } \\
\text { analysis. }\end{array}$ & SAGE Open Med. \\
\hline 1. & Veillard et al. & 2017 & & $\begin{array}{l}\text { Better Measurement for Performance Improvement in } \\
\text { Low- and Middle-Income Countries: The Primary } \\
\text { Health Care Performance Initiative (PHCPI) } \\
\text { Experience of Conceptual Framework Development } \\
\text { and Indicator Selection. }\end{array}$ & $\begin{array}{l}\text { The Milbank Quarterly; } \\
\text { 95(4) }\end{array}$ \\
\hline 2. & $\begin{array}{l}\text { National Academies of } \\
\text { Sciences, Engineering, } \\
\text { and Medicine }\end{array}$ & 2018 & & $\begin{array}{l}\text { Crossing the Global Quality Chasm: Improving } \\
\text { Health Care Worldwide }\end{array}$ & $\begin{array}{l}\text { Washington } \quad \text { (DC): } \\
\text { National Academies Press } \\
\text { (US) }\end{array}$ \\
\hline 73. & Barbazza et al. & 2019 & & $\begin{array}{l}\text { Creating performance intelligence for primary health } \\
\text { care strengthening in Europe. }\end{array}$ & $\begin{array}{ll}\text { BMC Health Services } \\
\text { Research, } 19 .\end{array}$ \\
\hline 4. & Levesque \& Sutherland & 2020 & & $\begin{array}{l}\text { Combining patient, clinical and system perspectives } \\
\text { in assessing performance in healthcare: an integrated } \\
\text { measurement framework }\end{array}$ & $\begin{array}{l}\text { BMC } \quad \text { Health } \\
\text { Research, } 20\end{array}$ \\
\hline 75. & Moura et al. & 2020 & & $\begin{array}{l}\text { Factors for performance measurement systems design } \\
\text { in nonprofit organizations and public administration. }\end{array}$ & $\begin{array}{lr}\text { Measuring } & \text { Business } \\
\text { Excellence, 24(3), 377-399. }\end{array}$ \\
\hline 86. & Zaadoud et al. & 2020 & & $\begin{array}{l}\text { Do performance measurement models have any } \\
\text { impact on primary health care? A systematic review }\end{array}$ & $\begin{array}{l}\text { International Journal of } \\
\text { Health Governance }\end{array}$ \\
\hline
\end{tabular}

